\title{
Nomuraea rileyi (Farlow) Samson Incidence on Spodoptera litura and Spodoptera frugiperda in Andhra Pradesh
}

\author{
Y. Peeru Saheb ${ }^{1 *}$, K. Manjula ${ }^{1}$, K. Devaki ${ }^{2}$, R. Sarada Jaya Lakshmi ${ }^{3}$, \\ B. Ravindra Reddy ${ }^{4}$ and N. C. Venkateswarlu ${ }^{1}$
}

${ }^{1}$ Department of Entomology, S.V. Agricultural College, Tirupati, Andhra Pradesh, India

${ }^{2}$ Department of Entomology, RARS, Tirupati, Andhra Pradesh, India

${ }^{3}$ Department of Plant Pathology,

${ }^{4}$ Department of Statistics and Computer applications, S.V. Agricultural College, Tirupati,

Andhra Pradesh, India

*Corresponding author

\section{A B S T R A C T}

Keywords

Nomuraea rileyi,

Spodoptera litura,

Spodoptera

frugiperda, infected

larvae

Article Info

Accepted:

10 January 2021

Available Online:

10 February 2021
Nomuraea rileyi is an important natural mortality causing agent of many lepidopterous pests in a variety of crop ecosystems throughout the world. The roving survey was conducted for the collection of Nomuraea rileyi infected lepidopteran caterpillars in field and horticultural crops in different Agroclimatic zones of Andhra Pradesh during September-October 2018; January-February 2019; September-October 2019 and January-February 2020. During the survey, it was found that the mean number of Nomuraea rileyi infected Spodoptera litura and Spodoptera frugiperda varied from 4.4 to 5.0 per square meter during September, 2018 and 2019 in Vishakapatnam distrcict in high altitude tribal zone. In Guntur district of Krishna zone mean number of Nomuraea rileyi infected larvae varied from 3.0 to 4.2 per square meter during January, 2019. In scarce rainfall zone of Kurnool district, the incidence of mean number of Nomuraea rileyi infected larvae varied from 2.2 to 4.0 per square meter during October 2019. In Chittoor of southern zone, mean number of Nomuraea rileyi infected larvae varied from 0.4 to 2.0 per square meter during October, 2019. The mean number of $N$. rileyi infected larvae of 0.2 per square meter during January, 2019 was noticed in Srikakulam district of north coastal zone. In Godavari zone incidence of Nomuraea rileyi infected larvae was not recorded.

\section{Introduction}

Nomuraea rileyi is a dimorphic, ubiquitous fungus with yeast-like hyphal bodies and true mycelial filaments and named initially as
Botrytis rileyi (Farlow) and later as Spicaria rileyi (Farlow) Charles. The fungus was redescribed and placed in the genus, Nomuraea by Kish et al., (1974). In culture plate, the colour of colonies of fungus, Nomuraea rileyi 
progresses from white to green to malachite green Devi (2000). Nomuraea rileyi (Farlow) Samson is an important entomopathogenic fungus causing natural mortality in as many as 51 lepidopteran insects throughout the world (Lingappa and Patil, 2002). In Andhra Pradesh, there are several reports on occurrence of $N$. rileyi on Spodoptera litura, and Helicoverpa armigera in the crops groundnut, castor, cotton, blackgram, redgram. Very recent reports revealed the infection of N.rileyi to the new invasive pest, Spodoptera frugiperda also. Study was taken up to collect, isolate and identify $N$. rileyi from different Agroclimatic zones of Andhra Pradesh.

\section{Materials and Methods}

A Roving survey was conducted for the collection of Nomuraea rileyi on lepidopteran caterpillars in field and horticultural crops in six agroclimatic zones of Andhra Pradesh. The survey was conducted four times $i$. $e$ during September-October, 2018; SeptemberOctober, 2019; January-February, 2019 and January-February, 2020. The districts selected in Agroclimatic zones of Andhra Pradesh were Srikakulam in North coastal zone, Visakhapatnam in High altitude tribal zone, West Godavari in Godavari zone, Guntur in Krishna zone, Chittoor in Southern zone and Kurnool in Scarce rainfall zone. In the selected district of each zone, four villages were selected. In each village, the major field and horticulture crops available were observed for $N$. rileyi infected cadavers of lepidopteran caterpillars.

The sampling fields were selected randomly in the village. From the fields the dead cadavers adhered to the leaves, any plant part with external signs of mycosis was collected with the help of fine brush into sterilized glass /plastic vials and plastic petriplates. After collection of entomopathogenci fungal cadavers into the vials and petriplates they were wrapped with parafilm and labelled with the details of date of collection, insect cadaver, crop, village, district and zone. The insect cadavers per square meter were counted at five places randomly in the field.

From entomopathogenic fungal cadavers collected during survey, the fungus was inoculated on to the SMAY medium in petriplates for confirmation of $N$. rileyi. After confirmation, pure cultures of isolates were named and maintained in the laboratory.

\section{Results and Discussion}

The Nomuraea rileyi infected larvae were observed to adher on husk of cob, at tips of cobs and in whorl of leaves. Sometimes death with head and posterior abdominal region in a raised position was seen. Most of the cadavers were found adhering to leaves. Some cadavers were with white fungal mat cover on body except head portion and some covered with light green spore mass. Relatively the cadavers covered with green spore mass were high in numbers. Mostly later instars of $S$. frugiperda (fourth and fifth instars) were seen as cadavers. While collecting the cadavers, green spore mass was being left on leaves or plant parts.

\section{Incidence of Nomuraea rileyi infected lepidopteran larvae in different agroclimatic zones}

\section{North Coastal zone}

In north coastal zone of Srikakulam district, EPF cadavers of Spodoptera litura were collected from blackgram crop in Ragolu and the least mean number of cadavers was found i.e. 0.2 per square meter during the survey conducted in second fortnight of January, 2019. During the above survey period, the average maximum, minimum temperatures 
recorded in North coastal zone were $32{ }^{\circ} \mathrm{C}$ and $14{ }^{\circ} \mathrm{C}$. The average morning and evening relative humidities recorded were $41 \%$ and 99\% respectively. Rainfall was not received during the period.

\section{High Altitude Tribal Zone}

During the survey conducted in September 2018, the EPF cadavers of Spodoptera frugiperda were collected in maize crop at Chintapalli and the mean number of cadavers found was 4.8 per square meter.

During second fortnight of September 2019, EPF cadavers of Spodoptera litura were recorded in groundnut crop in Rinthada and the mean number of cadavers found were 4.6 per square meter. Spodoptera frugiperda cadavers in maize in Pentapadu and Chintapalli were found and the mean number of cadavers found was 4.4 and 5.0 respectively per square meter. During the above survey periods, the average maximum, minimum temperatures recorded in High Altitude Tribal Zone were $27-30^{\circ} \mathrm{C}$ and $20^{\circ} \mathrm{C}$. The average morning and evening relative humidities recorded were $69-77 \%$ and $85-100 \%$ respectively. Rainfall of 115-269 $\mathrm{mm}$ was received.

\section{Godavari Zone}

$N$. rileyi cadavers were not found in Godavari zone. During the survey period, the average maximum, minimum temperatures recorded in Godavari zone were $33-35^{\circ} \mathrm{C}$ and $21-25^{\circ} \mathrm{C}$. The average morning and evening relative humidities recorded were $49-62 \%$ and $89-98 \%$ respectively. Rainfall received was 0.00 to 188 $\mathrm{mm}$.

\section{Krishna zone}

In krishna zone of Guntur district, EPF cadavers of Spodoptera litura were found in
Returu, Yajili and Dunduvaripalli in blackgram and groundnut and the mean number of cadavers found were 3.0, 4.2 and 3.2 respectively per square meter during the survey conducted in second fortnight of January, 2019. During the above survey period, the average maximum, minimum temperatures recorded in Krishna zone were $30-32^{\circ} \mathrm{C}$ and $14-18^{\circ} \mathrm{C}$. The average morning and evening relative humidities recorded were $41-51 \%$ and $95-99 \%$ respectively. Rainfall of $1 \mathrm{~mm}$ was received.

\section{Southern zone}

EPF cadavers of Spodoptera litura were observed in groundnut at Perumalapalli and the mean numbers of cadavers found were 0.6 per square meter, Spodoptera frugiperda cadavers in maize crop in Rayalapuram and Chandragiri were found and the mean number of cadavers found were 2.0 and 0.4 respectively per square meter during the survey conducted in second fortnight of October, 2019. EPF cadavers of S. litura were found in chillies in Agarala and the mean numbers of cadavers found were 0.4 per square meter in second fortnight of January, 2020 in Chittoor of Southern Zone.

During the above survey period, the average maximum, minimum temperatures recorded in Southern zone were $33-34^{\circ} \mathrm{C}$ and $17-22^{\circ} \mathrm{C}$. The average morning and evening relative humidities recorded were $45-60 \%$ and 99$100 \%$ respectively. Rainfall of $10-167 \mathrm{~mm}$ was received.

\section{Scarce rainfall zone}

EPF cadavers were found on Spodoptera frugiperda in maize crop in Noonepalli, Illurukothapeta, Harivaram and Velugodu and the mean number of cadavers found were 2.6, 2.2, 4.0 and 2.4 respectively per square meter during the survey in second fortnight of 
October, 2019 in Kurnool of Scarce rainfall Zone. During the above survey period, the average maximum, minimum temperatures recorded in Southern zone were $31-34^{\circ} \mathrm{C}$ and $23-24^{\circ} \mathrm{C}$. The average morning and evening relative humidities recorded were $53-71 \%$ and $87-100 \%$ respectively. Rainfall of $81-140 \mathrm{~mm}$ was received.

The findings of the present study reveal that considerably the higher density of $N$. rileyi infected lepidopteran larvae of 4.4 to 5.0 per square meter was found in High altitude tribal zone might be due to higher rainfall that creates good relative humidity and in this zone the usage of synthetic pesticides and fertilizers is very less which creates opportunity for the survival of soil fauna including the soil borne microorganisms like $N$. rileyi.

In Krishna zone also the incidence is good i.e. $N$. rileyi infected lepidopteran larvae of 3.0 to 4.2 per square meter were recorded. The blackgram and groundnut are the cover crops that maintain good soil moisture and sufficient relative humidity in crop ecosystem.

In scarce rainfall zone also $N$. rileyi incidence is satisfactory. Per square meter 2.2 to 4.0 N.rileyi infected lepidopteran larvae were recorded and in southern zone also the incidence of N.rileyi infected lepidopteran larvae of 0.4 to 2.0 per square meter were found.

The lower incidence of N.rileyi infected lepidopteran larvae of 0.2 per square meter in North coastal zone might be due to lower rainfall that generally create conditions that are not suitable for soil microbes like N.rileyi.

The incidence of N.rileyi was not found in Godavari zone. In Godavari zone, the crop surveyed was paddy and the reason for not finding any lepidopteran cadaver might be due to submerged field conditions which would not be favourable for the survival of $N$. rileyi inoculum in the soil. Among the crops surveyed higher density was observed in maize followed by groundnut, blackgram and chillies.

The maximum temperatures around $30^{\circ} \mathrm{C}$, minimum temperatures around $20^{\circ} \mathrm{C}$ and relative humidity more than $80 \%$ are the highly congenial weather conditions prevailed in High altitude tribal zone for N.rileyi to create this epizootic condition. Moreover, soils in this zone may be most suitable to hold the viability and virulence of N.rileyi in the absence of the crop (Table 1).

In Krishna zone and Southern zone also, the temperatures and humidity were observed to be favourable for N.rileyi. So that good incidence of $N$.rileyi was recorded.

The present results are supported by Mallapur et al., (2018) who conducted field survey in maize crop in Northern Karnataka during kharif, 2018. In these surveys, they found the natural incidence of entomopathogenic fungi, Nomuraea rileyi on Spodoptera frugiperda with its infection ranging from 1.87 per cent in Vijaypur to 18.30 per cent in Dharwad district. Nidhi et al., (2018) reported that maximum mean number of Nomuraea rileyi infected Trichoplusia orichalcea on soybean were recorded as 0.8 followed by 0.4 per meter square at Fatehpur and Kaelakhera area of Udham Singh Nagar district in the month of September (2014-2015) during the extensive survey conducted for collection of entomopathogenic fungi affected insect cadavers in Uttarakhand.

Barad et al., (2015) conducted a field experiment to determine the natural occurrence of Nomuraea rileyi on Helicoverpa armigera in pigeonpea ecosystem at Agricultural University campus, Junagadh during kharif seasons of 2008 and 2009. 


\begin{tabular}{|c|c|c|}
\hline $\begin{array}{c}\text { Fig.1 Nomuraea rileyi } \\
\text { infected Spodoptera } \\
\text { frugiperda larva in } \\
\text { maize }\end{array}$ & $\begin{array}{c}\text { Fig.2 Nomuraea rileyi } \\
\text { infected Spodoptera } \\
\text { litura larva in } \\
\text { groundnut }\end{array}$ & $\begin{array}{c}\text { Fig.3 Nomuraea rileyi infected } \\
\text { Spodoptera litura larva in blackgram }\end{array}$ \\
\hline & & \\
& &
\end{tabular}

Table.1 Crops surveyed and the incidence of N.rileyi in different agroclimatic zones of Andhra Pradesh

\begin{tabular}{|c|c|c|c|c|c|}
\hline $\begin{array}{l}\text { S. } \\
\text { no }\end{array}$ & $\begin{array}{c}\text { Zone } \\
\text { (District) }\end{array}$ & Village & Crop & $\begin{array}{c}\text { Cadavers of } \\
\text { Lepidopteran } \\
\text { larvae } \\
\text { noticed }\end{array}$ & $\begin{array}{c}\text { Mean no. } \\
\text { of } \\
\text { cadavers/ } \\
\text { sq.m }\end{array}$ \\
\hline \multirow[t]{8}{*}{1.} & $\begin{array}{l}\text { High altitude tribal Zone } \\
\text { (Vishakapatnam) } \\
\text { II Fortnight,September, } 2018\end{array}$ & i)Choudupalli & cabbage & Nil & \\
\hline & & & carrot & Nil & \\
\hline & & & paddy & Nil & \\
\hline & & ii)Gadidamitta & brinjal & Nil & \\
\hline & & & sweetpotato & Nil & \\
\hline & & iii)Chintapalli & maize & $\begin{array}{c}\text { Spodoptera } \\
\text { frugiperda } \\
\text { (Fall army } \\
\text { worm) }\end{array}$ & 4.8 \\
\hline & & & paddy & Nil & \\
\hline & & iv)Bagata & paddy & Nil & \\
\hline \multirow[t]{2}{*}{2.} & $\begin{array}{l}\text { North Coastal Zone } \\
\quad \text { (Srikakulam) } \\
\text { II Fortnight, January, } 2019\end{array}$ & i)Naira & $\begin{array}{l}\text { sweet corn, } \\
\text { paddy } \\
\text { followed } \\
\text { blackgram } \\
\text { and } \\
\text { greengram }\end{array}$ & Nil & \\
\hline & & ii)Bavajipeta & $\begin{array}{l}\text { brinjal, } \\
\text { chilli and } \\
\text { groundnut }\end{array}$ & Nil & \\
\hline
\end{tabular}




\begin{tabular}{|c|c|c|c|c|c|}
\hline & & iii)Mannayyapeta & $\begin{array}{l}\text { Fingermillet } \\
\text { and } \\
\text { Sesamum }\end{array}$ & Nil & \\
\hline & & iv)Ragolu & $\begin{array}{c}\text { paddy } \\
\text { fallowed } \\
\text { blackgram }\end{array}$ & $\begin{array}{c}\text { Spodoptera } \\
\text { litura } \\
\text { (Tobacco } \\
\text { caterpillar) }\end{array}$ & 0.2 \\
\hline \multirow[t]{4}{*}{3.} & $\begin{array}{c}\text { Krishna Zone } \\
\text { (Guntur) }\end{array}$ & i)Narakoduru & $\begin{array}{l}\text { brinjal and } \\
\text { chilli }\end{array}$ & Nil & \\
\hline & & ii)Returu & $\begin{array}{c}\text { paddy } \\
\text { followed } \\
\text { blackgram }\end{array}$ & $\begin{array}{c}\text { Spodoptera } \\
\text { litura } \\
\text { (Tobacco } \\
\text { caterpillar) }\end{array}$ & 3.0 \\
\hline & & iii)Yajili & $\begin{array}{c}\text { paddy } \\
\text { followed } \\
\text { blackgram } \\
\text { and } \\
\text { greengram }\end{array}$ & $\begin{array}{c}\text { Spodoptera } \\
\text { litura } \\
\text { (Tobacco } \\
\text { caterpillar) }\end{array}$ & 4.2 \\
\hline & & iv)Dunduvaripalli & groundnut & $\begin{array}{c}\text { Spodoptera } \\
\text { litura } \\
\text { (Tobacco } \\
\text { caterpillar) }\end{array}$ & 3.2 \\
\hline \multirow[t]{4}{*}{4.} & $\begin{array}{l}\text { High Altitude Tribal Zone } \\
\text { (Vishakapatnam) } \\
\text { II Fortnight September, } 2019\end{array}$ & i)Rinthada & groundnut & $\begin{array}{c}\text { Spodoptera } \\
\text { litura } \\
\text { (Tobacco } \\
\text { caterpillar) }\end{array}$ & 4.6 \\
\hline & & ii)Pentapadu & maize & $\begin{array}{c}\text { Spodoptera } \\
\text { frugiperda } \\
\text { (Fall army } \\
\text { worm) }\end{array}$ & 4.4 \\
\hline & & iii)Chintapalli & maize & $\begin{array}{c}\text { Spodoptera } \\
\text { frugiperda } \\
\text { (Fall army } \\
\text { worm) }\end{array}$ & 5.0 \\
\hline & & iv)Choudupalli & maize & Nil & \\
\hline \multirow[t]{3}{*}{5.} & $\begin{array}{l}\text { Southern Zone (Chittoor) } \\
\text { II Fortnight October, } 2019\end{array}$ & i) Rayalapuram & maize & $\begin{array}{c}\text { Spodoptera } \\
\text { frugiperda } \\
\text { (Fall army } \\
\text { worm) }\end{array}$ & 2.0 \\
\hline & & ii) Chandragiri & maize & $\begin{array}{c}\text { Spodoptera } \\
\text { frugiperda } \\
\text { (Fall army } \\
\text { worm) }\end{array}$ & 0.4 \\
\hline & & iii) Perumalapalli & groundnut & Spodoptera & 0.6 \\
\hline
\end{tabular}




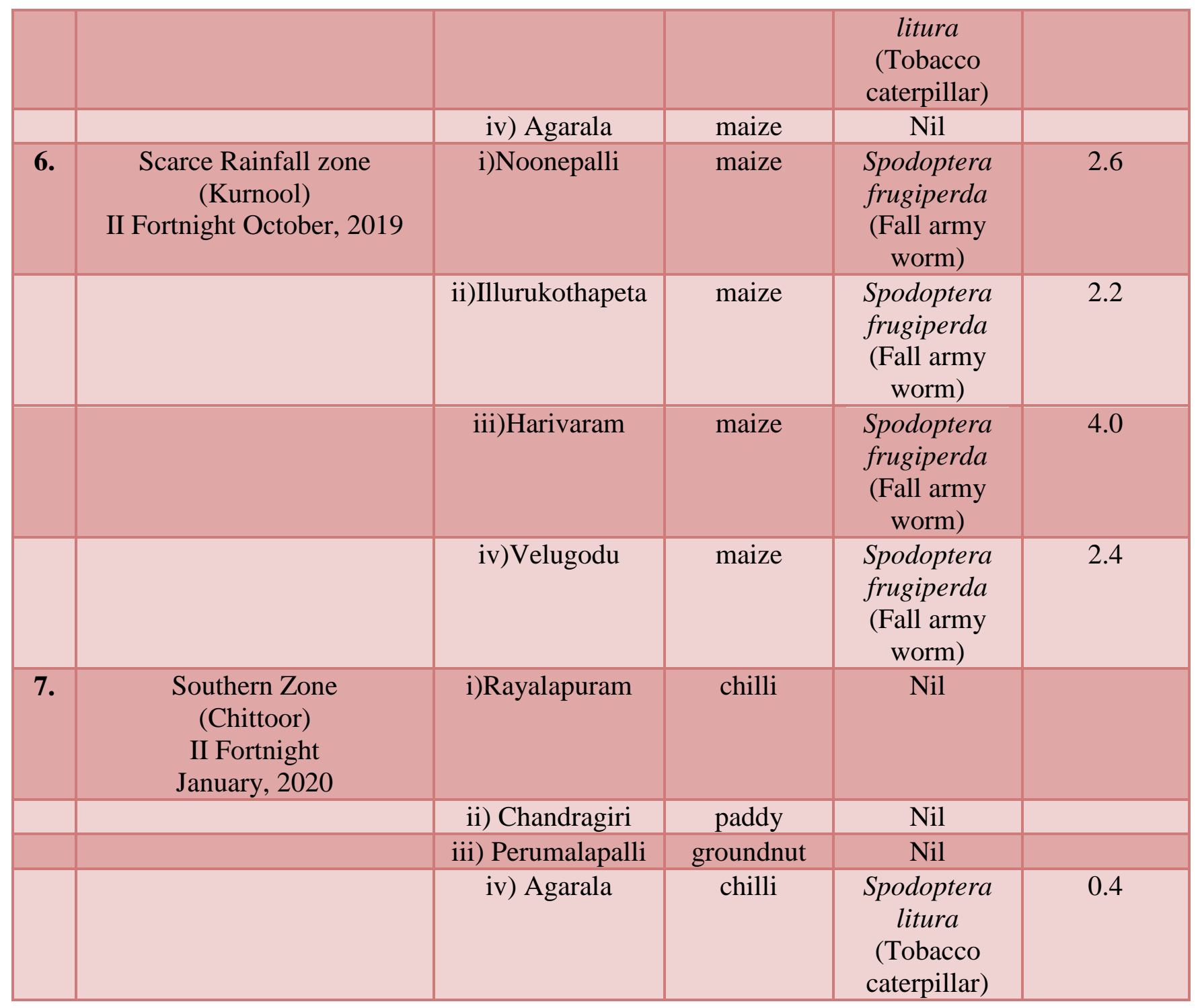

The results revealed $N$. rileyi naturally infected H.armigera larvae up to $14.0 \%$ during both the pigeonpea seasons. Its infection was observed maximum during late August and mid-September to late October. Correlation study indicated that the fluctuation in parasitism of $H$. armigera by $N$. rileyi showed a strong positive correlation with host density and relative humidity. Dutta et al., (2014) studied that during the months of MayJune, 2012, crops were surveyed for the larvae of Spodoptera litura and its natural enemies in Instruction cum Research farm and Horticultural Orchard, AAU, Jorhat, Assam, India. The larvae of $S$. litura found dead due to fungal infection to the extent of $80-90$ per cent. Infected larvae with or without fungal growth were found died and found attached on plant parts or hang in "V" shaped remaining attached to plant parts or fallen on the ground. The diseased larvae were mummified and covered with dense white and faded green cottony fungal growth over the entire surface of the body.

Devi et al., (2003) reported that the entomopathogenic fungus Nomuraea rileyi causes severe natural infection of important lepidopteran pests viz., Helicoverpa armigera (Hubner), Spodoptera litura (Fab.) and 
Chrysodeixis spp. that attacks several economically important crops. Manjula et al., (2003) recorded for the first time infection of Nomuraea rileyi on Helicoverpa armigera larvae during October in scarce rainfall zone of Andhra Pradesh in kharif groundnut. She stated that, the receipt of good rains during September and October months resulted in the luxuriant crop growth which maintained high humidity in the ecosystem. The temperature and relative humidity during the period of maximum occurrence of Nomuraea rileyi were $21-23^{\circ} \mathrm{C}$ and $79-84 \%$ respectively.

Hemasree (2010) reported that in the roving survey conducted during January, 2010, incidence of Nomuraea rileyi infected lepidopteran caterpillars in groundnut were observed in the village of Naachaneru, Srikalahasti division of Chittoor district.

Devi et al., (1996) opined that the period between July to September is more favourable for $N$. rileyi incidence. The most favourable period for the pathogen has been from July to September in the transitional tract when the crop is most amenable for high incidence of defoliators and prevalence of cloudy and humid weather. Burleigh (1975) observed the higher infection of Nomuraea rileyi in Heliothis sp. larvae collected from a closed canopy of cotton (Delta pine 215) than collected from an open canopy variety (Louisiana Okraleaf). Namasivayam et al., (2013) observed natural occurrence of major fungal entomopathogen $N$. rileyi associated with agricultural field soil in an area around Tamil Nadu, India. Agricultural field soil samples were collected from ten different sites. A total of 123 isolates of N.rileyi were obtained. Among the 10 sampling sites, $N$. rileyi was isolated from 4 sites belonging to Hasthampatty (Salem) Rajakoil (Vellore) Vadavali (Coimbatore), Pullarakottai (Viruthunagar), High frequency of fungal occurrence was recorded in vadavali $(60 \%)$ followed by Pullarakottai (17\%), Hasthampatty (13\%) and Rajakoil(10\%).

\section{Acknowledgement}

The authors are thankful to Dr. Ramesh Naik, SMS (Plant Protection), KVK, Banavasi and Dr. Ramana, Scientist (Soil Science \& Agriculture Chemistry), RARS, Chintapalli, for their help during the survey.

\section{References}

Barad, A.H., Kapadia, M.N. and Jethva, D.M. 2015. Natural Occurrence of Nomuraea rileyi on Helicoverpa armigera in Pigeonpea Ecosystem. Indian Journal of Plant Protection. 43 (2): 163-166.

Burleigh, J.G. 1975. Comparison of Heliothis spp. larval parasitism and Spicaria infection in closed and open canopy cotton varieties. Environmental Entomology. 4: 574-576.

Devi, P.S.V. 2000. Potential use of Nomuraea as a microbial pesticide in India. In :Emerging Trends in Microbial Control of Crop Pests (eds. Robindra, R.J. and Others.) pp. 155-168.

Devi, P.S.V., Prasad, Y.G., Chowdary, D.A., Rao, L.M. and Balakrishnan, K. 2003. Identification of virulent isolates of the entomopathogenic fungus Nomuraea rileyi (F.) Samson for the management of Helicoverpa armigera and Spodoptera litura. Mycopathologia. 156: 365-373.

Devi, P.S.V., Prasad, Y.G., Rajeswari, B. and Bhaskar, C.V. 1996. Epizootics of the entomofungal pathogens, Nomuraea rileyi on lepidopterous pests of oilseeds. Journal of Oilseeds Research. 13 : 144-148.

Dutta, P.P., Patgiri, J., Pegu, Kaushik, H and Boruah, S. 2014. First record of Nomuraea rileyi (Farlow) Samson on 
Spodoptera litura Fabricius (Lepidoptera: Noctuidae) from Assam, India. Current Biotica. 8(2): 187-190.

Hemasree, E. 2010. Studies on Entomopathogenic Fungi with special reference to Nomuraea rileyi (Farlow) Samson Against Semiloopers. Thesis submitted to Acharya N.G. Ranga Agricultural University.

Kish, L.P., Samson, R.A and Allen, G.E.1974. The genus Nomuraea Maublanc. Journal of Invertebrate Pathology. 24(2):154-158

Lingappa, S. and Patil, R.K. 2002. Nomuraea rileyi -A potential Mycoinscticide. University of Agricultural Sciences, Dharwad, $40 \mathrm{p}$.

Mallapur, C.P., Naik, A.K., Hagari, S., Praveen, T., Patil, R.K. and Lingappa, S. 2018. Potentiality of Nomuraea rileyi (Farlow) Samson against the Fall armyworm, Spodoptera frugiperda (J E Smith) infesting maize. Journal of
Entomology and Zoology Studies. 6(6): 1062-1067.

Manjula, K., Nagalingam, B. and Rao, P.A. 2003. Occurrence of Nomuraea rileyi on Helicoverpa armigera and Spodoptera litura in Guntur district of Andhra Pradesh. Annals of Plant Protection Sciences. 11: 224-227.

Namasivayam, K.R., Bharani, R.S.A. and Ansari M.R. 2013. Natural Occurrence of Potential Fungal Biopesticide Nomuraea Rileyi (Farlow) Samson Associated with Agriculture Fields of Tamil Nadu, India and it's Compatibility with Metallic Nanoparticles. Journal of Biofertilizers and Biopesticides. 4: 132.

Nidhi, K., Gaur, N. and Pandey, R.A. 2018. Survey of the local isolates of entomopathogenic fungi in Uttarakhand region. Journal of Entomology and Zoology Studies. 6(1): 1725-1730.

\section{How to cite this article:}

Peeru Saheb, Y., K. Manjula, K. Devaki, R. Sarada Jaya Lakshmi, B. Ravindra Reddy and Venkateswarlu, N. C. 2021. Nomuraea rileyi (Farlow) Samson Incidence on Spodoptera litura and Spodoptera frugiperda in Andhra Pradesh. Int.J.Curr.Microbiol.App.Sci. 10(02): 12621270. doi: https://doi.org/10.20546/ijcmas.2021.1002.149 